\title{
ANALYSIS OF FACTORS AFFECTING CUSTOMER SATISFACTION AND CUSTOMER RETENTION ON E-COMMERCE
}

\author{
Dewi Nuraini ${ }^{\mathrm{a}}$ \\ Achsania Hendratmi ${ }^{b}$ \\ ${ }^{a, b}$ Islamic Economics Department, Faculty of Economics and Business, University of Airlangga \\ dewi.nuraini-2017@feb.unair.ac.id ${ }^{a}$; achsania.hendratmi@feb.unair.ac.id ${ }^{b}$
}

\begin{abstract}
ARTICLE HISTORY
ABSTRACT

Received:

16 March 2021

Revised

05 October 2021

Accepted:

19 November 2021

Online available:

30 November 2021

Keywords:

Website Quality, Brand Image, Islamic Physical Attributes,

Customer Satisfaction, Customer Retention.

*Correspondence: Name: Dewi Nuraini

This study aims to analyze the factors that influence consumer retention on the e-commerce website Hijup. This study uses website quality, brand image, and Islamic physical attributes as factors that will shape customer satisfaction which in turn will affect customer retention. This research is quantitative research using two types of data, namely primary data and secondary data. Primary data is obtained by distributing online questionnaires through social media, and secondary data is obtained from books, journals, papers, websites, etc. The number of respondents used in this study were 185 respondents from Hijup consumers who had bought online more than once. This study uses the type of SEM-PLS analysis with SMARTPLS 3.0 software tools. This study shows that website quality and brand image affect customer satisfaction. Moreover, customer satisfaction is able to moderate website quality and brand image on customer retention on the Hijup website, but Islamic physical attributes have a negative relationship with customer satisfaction.
\end{abstract}

Email: dewi.nuraini-

2017@feb.unair.ac.id

\section{INTRODUCTION}

The use of Information and Communication Technology (ICT) by people in Indonesia has recently shown rapid development. According to data taken from the Central Statistics Agency (BPS), internet usage has faced an increase throughout the 2014-2019 period, this is shown by the increasing percentage of the population towards internet access in 2014, namely around 17.14 percent to 39.90 percent in 2018 (Central Statistics Agency (BPS), 2019). People take advantage of the use of the internet to buy or sell merchandise. This event is commonly known by electronic commerce or e-commerce.

E-commerce has grown at an exponential rate during the unprecedented COVID-19 pandemic (Barnes et al., 2021; Sheth, 2020). All forms of business, both large and small, have realized the potential for selling products online/via the internet. E-commerce can increase the totality of a company's business value. So, it is 
very important to understand the types of e-commerce businesses, one of which is in the form of a website. E-commerce in the form of a website has many types, one of which is shopping malls. This business model is almost the same as a marketplace, but sellers who can sell there must be well-known sellers or brands because there is a strict verification process or are generally grouped with the B2B/B2C group, for example such as Blibli.com, zalora.com (Pradana, 2015).

The data obtained from the Kompas.com website, one of Indonesia's online marketplace platforms, is that Tokopedia released the Indonesian online shopping trend in 2019. The most sought-after product in Indonesian online shopping is the fashion category. Based on statistical data obtained from the Statistics Research Department regarding the most popular e-commerce websites for fashion in Indonesia as of the second quarter of 2020, it shows that Hijup is ranked seventh. Data reported from the official Hijup account, we know that Hijup is a pioneer of Islamic fashion e-commerce, which was the first in the world to be established in 2011.

Meanwhile, from this data, it shows that the position of Hijup is still inferior to some e-commerce in the form of other websites that were established after Hijup. This proves that competition in the world of e-commerce is very tight. With the many conveniences that consumers have, making business competition through the website even tighter. Therefore, in order to retain customers, the Hijup website must have a marketing program that is more innovative and creative.

An e-commerce, especially in the form of a website, must have a strategy to be able to get customers. According to Roy et al. (2017) in today's business world, sellers must know clearly about consumer behavior in choosing and buying the goods or services needed. Mathew (2021)says that retaining customers is cheaper than bringing in new customers. Acquiring new customers tends to cost sellers 5-25 times, because customer retention is largely the result of customer satisfaction and loyalty (Gallo, 2014).

Website quality is a tool for measuring the quality of websites developed by Barnes and Vidgen (2000). The research conducted by Amirahmadi et al. (2015), there are four factors that affect website quality, namely, website reliability, website design, website security, and customer service.

In addition, with the increasingly competitive e-commerce business environment today, according to Malik et al. (2012) building a brand image of a company is the most important thing for service companies because it is a strong determinant of product marketing. Malik et al. (2012) defined brand image as a brand relationship that is maintained in the minds of consumers which causes consumers to brand. According to Kotler and Keller (2016), brand image is also illustrated as the understanding and beliefs that are included in consumers' memories as a reflection of the associations stored in consumers' minds. 
Therefore, paying attention to customer wants and needs can increase sales of the products and services offered by an industry (Kotler et al., 2017). At present, Muslim consumers who are becoming the main force and are getting more and more attention from the e-commerce business world regarding the demand for goods and services in the world economy are Muslim consumers (Sobari et al., 2019). According to data from Global Religious Futures (2018), Indonesia is one of the countries with the largest Muslim population in the world. The number of Indonesians who embraced Islam in 2010 reached 209.12 million or around $87 \%$ of the total population. Furthermore, in 2020 , the Muslim population in Indonesia is estimated to reach 229.62 million.

Because Indonesia is a Muslim-majority country, the halal business in Indonesia has enormous capabilities. Buyers in general will like goods or places to shop according to their character (Fauzi et al., 2016). As a result, religious perspectives on other purchasing decisions are preferred over other segmentation variables, such as demographic characteristics of age and life stage, which have traditionally been used to identify market segments (Gardiner et al., 2012)

According to Fariz (2018), for an Islamic based retail store that has a target, namely Muslim buyers who really pay attention to the suitability of Islamic quality to the goods they use, it is very important to offer value that is reflected in Islamic store attributes. In this research, in general, describe Islamic store attributes as characters that are in accordance with the Islamic values that the company offers to its customers. Meanwhile, according to Tariq et al. (2016), store attributes have a positive effect on satisfaction.

Based on current conditions, there are a lot of e-commerce in Indonesia. Consumer interest to shop online is increasing. As a country with a Muslim majority, e-commerce owners must know the right strategy to use in order to retain their customers. In previous studies, Islamic physical attributes were used to measure customer satisfaction at offline stores. In this study, the Islamic physical attributes variable is used for website-based e-commerce by using several other variables such as website quality and brand image to measure customer satisfaction which will then mediate customer retention on the Hijup website.

\section{LITERATURE REVIEW}

\section{The Effect of Website Quality on Customer Satisfaction}

The Website Quality model is a development of the Service quality method which was previously widely used in measuring service quality where the research instrument on Website Quality was developed using the Quality Function Development (QFD) method (Napitupulu, 2017). Meanwhile according to Shin et al. (2013), website quality is a perception of the overall quality of internet shopping center sites according to the customer's opinion of view. 
According to Hansopaheluwakan (2021) the quality of a website plays an important role in attracting new customers to retain existing customers. According to Huang (2019), a website that has good quality is the main reason for a customer to decide whether to buy goods online or not. If the customer feels that the website visited has detailed and clear quality information, then the customer will have higher trust in the seller of the item.

According to Andry (2016), the quality of the website is currently a strategic issue in online interactions, especially through the website platform. to assess customer satisfaction, the quality of the services provided is the main focus that has the most influence on customer satisfaction (Johnston, 2004). Research conducted by Hasanov and Khalid (2015) proved that website quality has a positive impact on customer satisfaction. Based on the results of previous research, therefore the hypothesis shows that website quality has a significant effect on customer satisfaction.

$H_{1}$ : Website quality has a significant positive effect on customer satisfaction.

\section{The Effect of Brand Image on Customer Satisfaction}

At present, brand image has become an interesting topic of discussion in the marketing literature as stated by several experts (Lee \& Lim, 2020; Park \& Park, 2019). Park and Park (2019) also said that brand image has become an important role in distinguishing companies and using good marketing media. According to Rahi and Ghani (2016), a brand is a product identity and an image that explains whether the brand is valuable or not. Brand image is also illustrated as understanding and beliefs that are embedded in the client's memory as a reflection of the associations that exist in the client's mind (Kotler \& Keller, 2016). According to Egan (2014), the brand image of a company is also very important for the products or services offered. Most of the business organizations consider brand image to be a strong asset for their business success. A trusted and recognized brand identity gives customer's confidence to use the products offered by the brand. Therefore, successful organizations always work hard to build strong brands and present them consistently and clearly.

Rahi and Ghani (2016) explained that brand image research emphasizes product identity, when the item has a special quality, it will create an image in the eyes of customers and will form a proper brand image. Therefore, to maintain the brand character, it is very important to maintain the consistency of quality and service. This study also reveals that getting customer consideration through service and quality is the best way to build a solid image in the customer's personality. Linking brand image and customer satisfaction, previous scientists (Anwar et al., 2019; Hsieh et al., 2018; Neupane, 2015) have shown that brand image is a 
determinant of customer satisfaction; it positively affects customer satisfaction. Thus, the hypothesis shows that brand image has a significant effect on customer satisfaction.

$\mathrm{H}_{2}$ : Brand image has a significant positive effect on customer satisfaction.

\section{The Effect of Islamic Physical Attributes on Customer Satisfaction}

Islamic physical attributes are considered very important for a Muslim when deciding to buy a product. As research conducted by Battour et al. (2010) as well as Eid and El-Gohary (2014), Islamic physical attributes and Islamic non-physical attributes of destinations that can attract Muslim tourists, such as facilities for prayer, halal food, Islamic entertainment, Islamic dress code, general Islamic morality, and azan.

According to the traditional model made by Ajzen and Fishbein (1980), it explained that relationship between beliefs, attitudes and behavior. McDaniel and Burnett (1990) recommend that the use of this model in retail context shows that consumer attitudes towards retail stores are a function of: 1 ) the level of consumer interest in the attributes; and 2) consumers' opinion in retail stores that have their respective attributes.

Shop attributes have dissimilar components of a store which contain prices, merchandise, facilities, various products, and services that consumers evaluate and consider in determining which stores that interesting to visit (Hashim et al., 2014). Usman (2015) concluded that the store image is built on various shop attributes which are combined to meet the needs and desires of consumers.

In addition, customer satisfaction is the main goal that must be obtained by service providers. Oliver (1997) defined satisfaction as a customer response in the form of an assessment that a product or service feature itself is a fulfillment of needs. Based on the explanation above, the hypothesis shows that Islamic physical attributes have a significant effect on customer satisfaction.

$H_{3}$ : Islamic physical attributes have a significant positive effect on customer satisfaction.

\section{The Effect of Customer Satisfaction on Customer Retention}

The definition of customer satisfaction according to Priansa (2017) is the feeling that someone feels both happy and disappointed that arises after comparing expectations with the performance results of a product. If the work results are below expectations, the customer will feel disappointed. If the work results meet expectations, the customer will be happy. And if the work exceeds expectations, the customer is very satisfied.

According to Chen and Liu (2017), customer retention is an assessment of the quality of the product/service provided by a business that measures how loyal the 
customer is. According to Chikako and Hamu (2021), customer satisfaction is a measure of how the products and services provided by the company meet or exceed customer expectations. It is also said that the perceived quality of service is high, it will lead to an increase in customer satisfaction. Several researchers found that customer satisfaction significantly affects customer retention in various sectors (Daneshfar et al., 2016; Nguyen et al., 2018) and also argued that customer satisfaction would increase customer retention. Based on the explanation above, the hypothesis shows that customer satisfaction has a significant relationship with customer retention.

$\mathrm{H}_{4}$ : Customer satisfaction has a significant positive effect on customer retention.

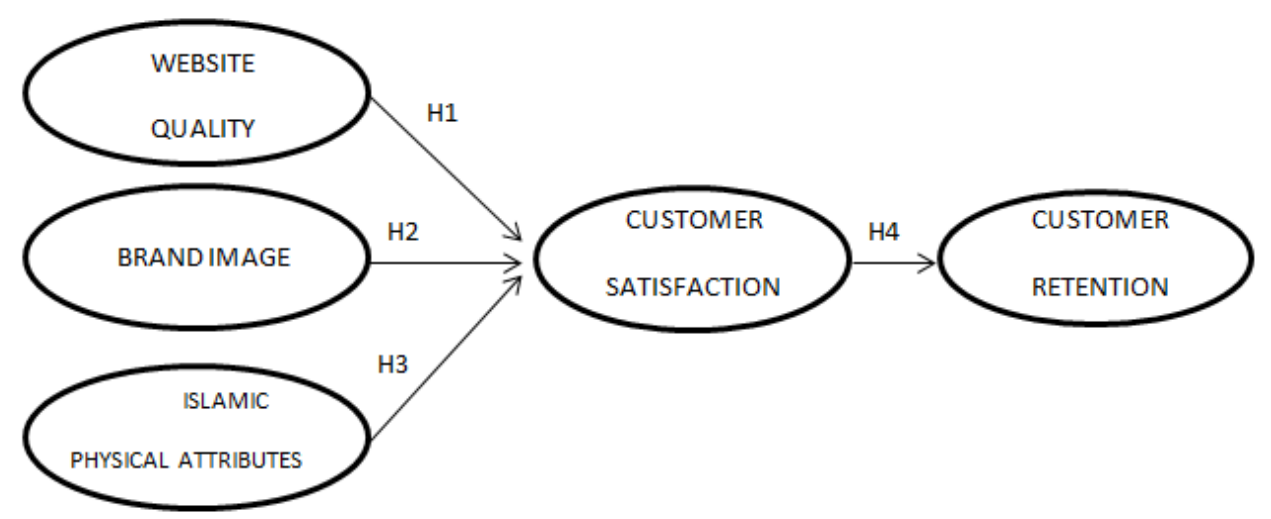

Figure 1. Conceptual Framework

\section{RESEARCH METHODS}

This research approach uses a quantitative approach. According to Hair et al. (2006), quantitative research is an approach that is more concerned with measurement and sampling methods because it uses a deductive approach that emphasizes detailed priorities in data collection and analysis. The subjects in this study were Hijup consumers who had made purchases through the official Hijup website, and had made purchases more than one time. Questionnaires were distributed online through social media, obtained 185 respondents who can be analyzed further.

Sources of data in this study consisted of primary data and secondary data. Primary data is obtained through sources that are collected directly so that the research objectives can be achieved, while secondary data is collected as supporting data and references used by researchers based on previous research. The research instrument uses a Likert scale (1-5) to measure a variable. Research modeling using Structural Equation Modeling-Partial Least Square (SEM-PLS) is applied to minimize 
the risk of error in the measurement of variables due to perceptual construct-based assessments (Ringle et al., 2015). SmartPLS 3.0 was chosen to analyze SEM-PLS because it makes it very easy to interpret analysis, and because PLS is based on variance, the number of samples used does not need to be large. The sample used can range from 30 to 100 . In addition to being able to test complex structural models, the results of path analysis can be carried out in one regression analysis.

\section{Characteristics Based on Screening Questions}

Screening questions regarding having purchased Hijup products through the Hijup official website aim to find out that respondents who filled out the questionnaire met the predetermined requirements. From the results of data processing, the total number of respondents who filled out the online questionnaire was 197 respondents. With a total of 193 respondents or $97.96 \%$ who answered "Yes" and 4 respondents or $2.04 \%$ who answered "No".

Table 1

Respondent Profile Description based on the Screening Question

\begin{tabular}{ccc}
\hline Screening Question & Frequency & Percentage \\
\hline Yes & 193 & $97.96 \%$ \\
No & 4 & $2.04 \%$ \\
Total & 197 & $100 \%$ \\
\hline
\end{tabular}

Source: Data Processed

Screening questions about having purchased Hijup products through the Hijup official website more than once aims to find out that the respondent who filled out the questionnaire met the predetermined requirements. From the results of data processing, the total number of respondents who filled out the online questionnaire was 197 respondents. With a total of 185 respondents or $93.9 \%$ who answered "Yes" and twelve respondents or $6.1 \%$ who answered "No". Based on those results, the number of respondents who met the requirements was 185 respondents.

Table 2

Respondent Profile Description based on the Screening Question

\begin{tabular}{ccc}
\hline Screening Question & Frequency & Percentage \\
\hline Yes & 185 & $93.9 \%$ \\
No & 12 & $6.1 \%$ \\
Total & 197 & $100 \%$ \\
\hline
\end{tabular}

Source: Data Processed

\section{Characteristics of Respondents by Age}

Table 3

Characteristics of Respondents by Age

\begin{tabular}{ccc}
\hline AGE & AMOUNT & PERCENTAGE \\
\hline $\mathbf{2 0 - 2 5}$ & 120 & $65 \%$ \\
$\mathbf{2 5 - 3 0}$ & 29 & $16 \%$ \\
\hline
\end{tabular}




\begin{tabular}{cccc}
\hline $\mathbf{3 0}-\mathbf{3 5}$ & 33 & $18 \%$ \\
$\mathbf{3 5 - 4 5}$ & 2 & $1 \%$ \\
$\mathbf{4 5 - 6 0}$ & 1 & $1 \%$ \\
TOTAL & $\mathbf{1 8 5}$ & $\mathbf{1 0 0 \%}$ \\
\hline
\end{tabular}

Source: Data Processed

The characteristics of respondents based on age are intended to determine the age range of respondents who have purchased Hijup through the official website and have made purchases more than once. From the results of data processing, respondents who have an age range of 20-25 years are 120 people and a percentage of $65 \%$, respondents aged $25-30$ years are 29 people with a percentage of $16 \%$, respondents aged $30-35$ years are 33 people with a percentage of $18 \%$, respondents aged 35 - 45 years amounted to 2 people with a percentage of $1 \%$, respondents aged $45-60$ years amounted to 1 person with a percentage of $1 \%$, respondents.

\section{Characteristics of Respondents by Occupation}

\begin{tabular}{lcc}
\multicolumn{3}{c}{ Table 4} \\
\cline { 2 - 4 } Characteristics by Occupation \\
\cline { 2 - 4 } POLEFSION & AMMOUNT & PERCENTAGE \\
CIVIL SERVANTS & 60 & $32 \%$ \\
EMPLOYEES & 28 & $15 \%$ \\
ENTREPRENEUR & 56 & $30 \%$ \\
TOTAL & 41 & $\mathbf{2 2 \%}$ \\
\hline
\end{tabular}

Source: Data Processed

The characteristics of respondents based on occupation are intended to determine the occupation of respondents who have made Hijup purchases through the official website and have made purchases more than once. From the results of data processing, respondents who work as students are 60 people with a percentage of $32 \%$, respondents with civil servant jobs are 28 people with a percentage of $15 \%$, respondents with employee jobs are 56 people with a percentage of $30 \%$, respondents with entrepreneurial jobs are 41 people with a percentage of $22 \%$.

\section{Characteristics of Respondents by Location}

Table 5

Characteristics by Location

\begin{tabular}{lcc}
\hline \multicolumn{1}{c}{ Province } & Amount & Percentage \\
\hline DKI Jakarta & 12 & $6 \%$ \\
East Java & 43 & $23 \%$ \\
West Java & 9 & $5 \%$ \\
DI Yogyakarta & 31 & $17 \%$ \\
West Nusa Tenggara & 15 & $8 \%$ \\
Riau & 17 & $9 \%$ \\
Jambi & 8 & $4 \%$ \\
\hline
\end{tabular}

Published by University of Airlangga.

This is an open access article under the CC BY license (https://creativecommons.org/licenses/by-nc-sa/4.0/) 


\begin{tabular}{lcc}
\hline East Kalimantan & 25 & $14 \%$ \\
West Sumatera & 15 & $8 \%$ \\
South Sumatera & 10 & $5 \%$ \\
TOTAL & $\mathbf{1 8 5}$ & $\mathbf{1 0 0 \%}$ \\
\hline
\end{tabular}

Source: Data Processed

The characteristics of respondents based on location are intended to determine the occupation of respondents who have made Hijup purchases through the official website and have made purchases more than once. From the results of data processing, the largest number of respondent locations was in East Java Province with 43 respondents or 23\%, then DI Yogyakarta with 31 respondents or $17 \%$, East Kalimantan with 25 people or $14 \%$, Riau with 17 people. respondents or $9 \%$, NTB with 15 respondents or $8 \%$, West Sumatra 15 respondents or $8 \%$, South Sumatra with 10 respondents or $5 \%$, and West Java with 9 respondents or $5 \%$.

This study uses a sampling technique of non-probability sampling, which is a sampling technique that does not provide opportunities equal for each element or member. The type of non-probability sampling used in this study is the convenience sampling technique. According to Sekaran (2003) convenience sampling refers to the collection of information from members of the population that is conveniently available to provide it.

\section{RESULT AND ANALYSIS}

The results of the respondents' answers described refer to the average value (mean) of the answers to each variable on a Likert scale (which consists of five points). The analysis of the average value is based on five categories of intervals obtained from the following formula:

$$
\text { Interval Class }=\frac{\text { Highest score }- \text { Lowest score }}{\text { The number of classes }}=\frac{5-1}{5}=0,80
$$

Table 6

Category Average Respondents' Answers

\begin{tabular}{ll}
\hline \multicolumn{1}{c}{ Interval Class } & \multicolumn{1}{c}{ Category } \\
\hline $\mathbf{1 . 0 0}<$ mean $<\mathbf{1 . 8 0}$ & Strongly disagree \\
$\mathbf{1 . 8 0}<$ mean $<\mathbf{2 . 6 0}$ & Disagree \\
$\mathbf{2 . 6 0}<$ mean $<\mathbf{3 . 4 0}$ & Neutral \\
$\mathbf{3 . 4 0}<$ mean $<\mathbf{4 . 2 0}$ & Agree \\
$\mathbf{4 . 2 0}<$ mean $<\mathbf{5 . 0 0}$ & Strongly agree \\
\hline
\end{tabular}

Source: Data Processed

Table 7

Website Quality Variable Description

\begin{tabular}{lll}
\hline \multicolumn{1}{c}{ Indicator } & Mean & \\
\hline X1.1 & 4.076 & The display on the Hijup website helps me to get information easily \\
X1.2 & 4.200 & I find it helpful in product selection with the product search facility \\
X1.3 & 4.103 & Hijup website is visually appealing
\end{tabular}




\begin{tabular}{lll} 
X1.4 & 4.022 & Hijup website has complete tools \\
X1.5 & 4.124 & Hijup website has a professional look \\
X1.6 & 3.989 & Hijup website provides complete information \\
X1.7 & 3.924 & Hijup website can quickly and easily complete transactions \\
X1.8 & 4.103 & The product images on the Hijup website are as received \\
X1.9 & 4.157 & Product orders are sent according to the estimated time given \\
X1.10 & 4.308 & I got the product according to the order \\
X1.11 & 4.027 & I feel the privacy of my identity is protected by the Hijup website \\
X1.12 & 4.032 & Hijup website has adequate security features \\
X1.13 & 4.059 & I feel safe transacting with the Hijup website \\
X1.14 & 3.881 & When I have a problem, the Hijup website can help to solve it \\
X1.15 & 3.968 & Hijup website admin is willing to help me \\
X1.16 & 3.919 & Admin answered my questions quickly \\
X1.17 & 3.854 & Returns are relatively easy \\
& 4.004 & On average, respondents answered agree when assessing the overall quality \\
MEAN TOTAL & & of the site on the Hijup website \\
\hline
\end{tabular}

Source: Data Proccesed

The total mean of respondents' answers to questions regarding the website quality variable is 4.004 . Based on Table 7 , it is explained that the average respondents answered agree with the questions used to measure website quality on the Hijup website on customer satisfaction, so that it can make consumers want to keep shopping on the Hijup website.

Based on Table 7 above, the lowest mean is found in the customer service indicator X1.14 with a total of 3.881 which states that when I have a problem, the Hijup website can help to solve it. While the highest mean in the table above, is found in the reliability indicator X1.10 which states that I got the product according to the order.

Table 8

Brand Image Variable Description

\begin{tabular}{lll}
\hline \multicolumn{1}{c}{ Indicator } & Mean & \\
\hline X2.1 & 4.335 & Hijup products have models that follow current fashion trends \\
X2.2 & 4.346 & I feel that the Hijup brand has a positive meaning \\
X2.3 & 4.205 & I feel that using Hijup products can increase my self-confidence \\
X2.4 & 4.103 & Hijup products can provide a compelling appeal to consumers \\
X2.5 & 4.205 & Shopping at Hijup provides a pleasant experience \\
MEAN TOTAL & 4.239 & $\begin{array}{l}\text { On average, respondents answered strongly agree about the impression } \\
\text { that consumers have on Hijup products. }\end{array}$ \\
\hline
\end{tabular}

Source: Data Processed

The total mean of respondents' answers to questions regarding the brand image variable is 4.239. Based on Table 8 , it is explained that on average the respondents answered strongly agree with the questions used to measure brand image on Hijup products, towards customer satisfaction, so that it can make consumers want to keep shopping on the Hijup website. 
Based on Table 4.8 above, the lowest mean is found in the symbolic benefits indicator X2.4 with a total of 4.103 which states that Hijup Products can provide attractive attractiveness to consumers. Meanwhile, the highest mean in the table above is found in the symbolic benefits indicator X2.2 with a total of 4.346 which states that I feel that the Hijup brand has a positive meaning.

Table 9

Islamic Physical Attributes Variable Description

\begin{tabular}{|c|c|c|}
\hline Indicator & Mean & Information \\
\hline X3.1 & 4.465 & Hijup website provides a variety of fashion and various brands \\
\hline $\mathrm{X3.2}$ & 4.314 & Hijup website provides quality products with well-known brands \\
\hline X3.3 & 4.086 & Hijup products have a price that matches the quality \\
\hline X3.4 & 4.341 & The Hijup website displays a model that covers aurat \\
\hline X3.5 & 4.146 & $\begin{array}{l}\text { Hijup provides fashion product designs that are in accordance with Islamic } \\
\text { law }\end{array}$ \\
\hline X3.6 & 4.362 & The Hijup website accommodates the needs of Muslims in clothing \\
\hline MEAN TOTAL & 4.286 & $\begin{array}{l}\text { On average, respondents answered strongly agree about the Islamic facilities } \\
\text { found on the Hijup website and given to consumers }\end{array}$ \\
\hline
\end{tabular}

Source: Data Processed

The total mean of respondents' answers to questions regarding the Islamic physical attributes variable is 4.286. Based on Table 9 explains that the average respondents answered strongly agree with the questions used to measure Islamic physical attributes on the Hijup website, on customer satisfaction, so that it can make consumers want to keep shopping on the Hijup website.

Based on Table 9 above, the lowest mean is found in the Muslim product and service indicator or X3.3 with a total of 4.086 which states that Hijup products have prices that are in accordance with quality. Meanwhile, the highest mean in the table above is found in the X3.1 indicator with a total of 4.465 which states that the Hijup Website provides various fashions and various brands.

Table 10

Customer Satisfaction Variable Description

\begin{tabular}{lll}
\hline \multicolumn{1}{c}{ Indicator } & Mean & \\
\hline Y1.1 & 4.184 & Hijup products meet my expectations \\
Y1.2 & 4.151 & I am satisfied with the Hijup website \\
Y1.3 & 3.962 & $\begin{array}{l}\text { Hijup products can be a mainstay compared to other competitors } \\
\text { On average, respondents answered agree about the feelings felt by Hijup }\end{array}$ \\
MEAN TOTAL & 4.099 & $\begin{array}{l}\text { consumers, which emerged after comparing expectations with performance } \\
\text { results on Hijup products and websites. }\end{array}$ \\
\hline
\end{tabular}

Source: Data Processed

The total mean of respondents' answers to questions regarding the customer satisfaction variable is 4.099 . Based on Table 10 , it is explained that the average respondents answered agree with the questions used to measure customer satisfaction on the entire Hijup website so that consumers can continue to buy Hijup products through the official website.

Based on Table 10 above, the lowest mean is found in the reliability indicator Y1.3 with a total of 3.962 which states that Hijup Products can be a mainstay 
compared to other competitors. Meanwhile, the highest mean in the table above is found in the YI.1 expectation indicator with a total of 4.184 which states that the Hijup Product is in line with my expectations.

Table 11

Customer Retention Variable Description

\begin{tabular}{lll}
\hline \multicolumn{1}{c}{ Indicator } & Mean & \\
\hline Z1.1 & 4.146 & I will visit Hijup website again \\
Z1.2 & 4.232 & I use the promotion provided by the Hijup website \\
Z1.3 & 4.130 & I recommend Hijup Website to others \\
Z1.4 & 4.265 & $\begin{array}{l}\text { I say positive things about Hijup Website to others } \\
\text { On average, the respondents answered strongly agree with the tendency of } \\
\text { Mijup consumers in the future to continue shopping through the Hijup } \\
\text { website. }\end{array}$ \\
\hline
\end{tabular}

Source: Data Processed

The total mean of respondents' answers to questions regarding the customer satisfaction variable is 4.193. Based on Table 11 explains that on average the respondents answered strongly agree with the questions used to measure customer retention on the Hijup website.

Based on Table 11 above, the lowest mean is found in the Z1.3 indicator with a total of 4.13 which states that I recommend Hijup Website to others. While the highest mean in the table above, is found in the Z1.4 indicator with a total of 4.265 which states that I state positive things about the Hijup Website to others. 


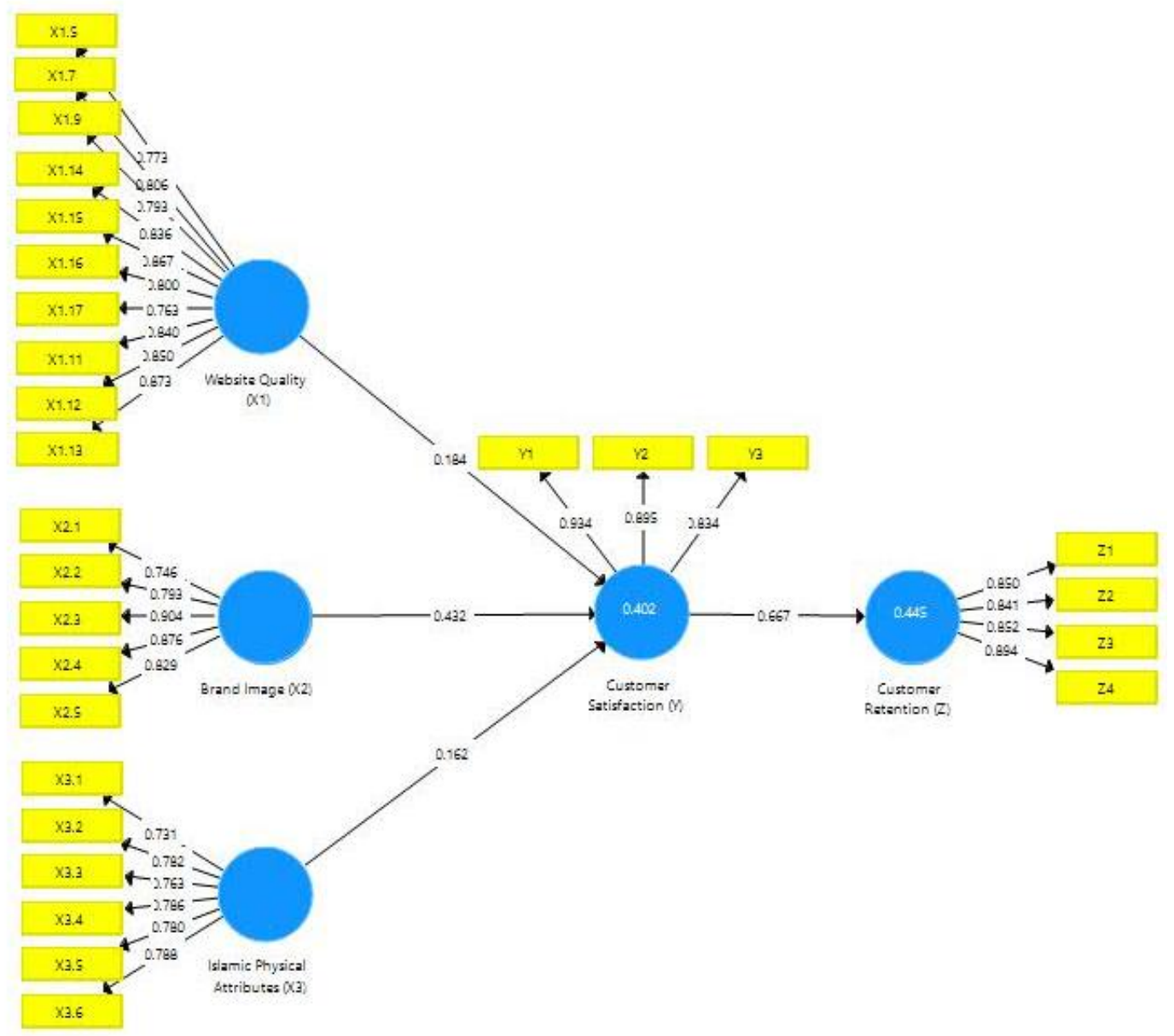

Figure 2. Construct Loading Factor

After doing three times the calculation of the loading factor, then all indicators have a loading factor $>0.7$ or equal to valid. By removing some indicators such as $\mathrm{X} 1.1, \mathrm{X} 1.3, \mathrm{X} 1.6, \mathrm{X} 1.8, \mathrm{X} 1.10$ in the first calculation, and removing $\mathrm{X} 1.2$ and $\mathrm{X} 1.4$ in the second calculation of the loading factor.

Average Variance Extracted or AVE is the average variance extracted by the program or it can be referred to as the value possessed by each variable (Hair et al., 2006). The minimum tolerable AVE value is 0.5 (Hair et al., 2006; Wijanto, 2015).

Table 12

AVE (Average Variance Extracted)

\begin{tabular}{lcccc}
\hline & $\begin{array}{c}\text { Cronbach's } \\
\text { Alpha }\end{array}$ & rho_A & $\begin{array}{c}\text { Composite } \\
\text { Reliability }\end{array}$ & $\begin{array}{c}\text { Average Variance } \\
\text { Extracted (AVE) }\end{array}$ \\
\hline WEBSITE QUALITY $\left(\mathbf{X}_{\mathbf{1}}\right)$ & 0.946 & 0.952 & 0.952 & 0.543 \\
BRAND IMAGE $\left(\mathbf{X}_{\mathbf{2}}\right)$ & 0.888 & 0.903 & 0.918 & 0.691 \\
ISLAMIC PHYSICAL ATTRIBUTES $\left(\mathbf{X}_{\mathbf{3}}\right)$ & 0.865 & 0.872 & 0.898 & 0.596 \\
CUSTOMER SATISFACTION $(\mathbf{Y})$ & 0.866 & 0.879 & 0.918 & 0.789 \\
CUSTOMER RETENTION $(\mathbf{Z})$ & 0.882 & 0.883 & 0.919 & 0.739 \\
\hline
\end{tabular}

Source: Data Processed

In table 12 the AVE value for each variable has a value> 0.5 , so all the variables used have met the requirements. 
Based on the results of testing the measurement model shown in Figure 2 and Table 12 it can be explained as follows:

1. Website quality is measured using $\mathrm{X} 1.5, \mathrm{X} 1.7, \mathrm{X} 1.9$, and $\mathrm{X} 1.11-\mathrm{X} 1.17$. All indicators have a loading factor above 0.7 and AVE $>0.5$.

2. The construct of brand image is measured using X2.1-X2.5. All indicators have a loading factor above 0.7 and AVE $>0.5$.

3. Islamic physical attributes constructs are measured using X3.1-X3.6. All indicators have a loading factor above 0.7 and $A V E>0.5$.

4. Customer satisfaction construct is measured using Y1.1-Y1.3. All indicators have a loading factor above 0.7 and AVE $>0.5$.

5. The customer retention construct is measured using Z1.1-Z1.4. All indicators have a loading factor above 0.7 and AVE $>0.5$.

Based on the results of the loading factors above, it can be concluded that the construct has good convergent validity.

Hypothesis testing conducted in this study was conducted to test the hypothesis and see the influence of exogenous variables on endogenous variables so that they could answer the research hypothesis. Testing this hypothesis by looking at the t-statistic must be>t-table of 1.96 .

Table 13

t-Statistics

\begin{tabular}{lcccccc}
\hline & $\begin{array}{c}\text { Original } \\
\text { Sample } \\
(\mathbf{O})\end{array}$ & $\begin{array}{c}\text { Sample } \\
\text { Mean (M) }\end{array}$ & $\begin{array}{c}\text { Standard } \\
\text { Deviation } \\
\text { (STDEV) }\end{array}$ & $\begin{array}{c}\text { t-Statistics } \\
(\mid \text { O/STDEV })\end{array}$ & P-Values & Description \\
\hline WQ (X1) -> CS (Y) & 0.184 & 0.190 & 0.070 & 2.623 & 0.009 & significant \\
BI (X2) -> CS (Y) & 0.432 & 0.433 & 0.107 & 4.022 & 0.000 & significant \\
IPA (X3) -> CS (Y) & 0.162 & 0.160 & 0.103 & 1.576 & 0.116 & insignificant \\
CS (Y) -> CR (Z) & 0.667 & 0.669 & 0.058 & 11.508 & 0.000 & significant \\
\hline
\end{tabular}

Source: Data Processed

Based on the results of the t-Statistics calculation above, the conclusions from the relationship between these variables are:

Hypothesis 1: From the results of hypothesis testing, it is found that the quality of the website has a positive effect on customer satisfaction. The results of this study support several previous studies as stated by Mohammad and Raeisi (2002) who stated that customer satisfaction is the result of website quality and trust. Furthermore, research from Siagian and Cahyono (2014) which shows the results of a positive and significant influence between website quality and customer satisfaction, and states that website quality is a medium for obtaining various information and can be a medium for making contact (contact) with online stores. Furthermore, the positive relationship between website quality and customer satisfaction is also explained by research conducted by Pradana and Puspitasari (2016). 
These results state that the better the website quality of the Hijup website, the higher the level of customer satisfaction felt by Hijup website consumers. Based on the results of the analysis, the t-statistic is 2.623 and the P-value is 0.009 . These results indicate that there is a direct influence of website quality on customer satisfaction.

Based on respondents' answers, the indicator with the highest mean obtained is included in the reliability category with an indicator of X1.9 with a mean of 4.157 in the agree category. Reliability on the Hijup website consists of two sub-chapters of measured dimensions, namely accurate product appearance and description and product delivery in accordance with the expected timeframe estimate. This is in accordance with research conducted by Fadhli (2015) which says that reliability is one of the most important factors that can shape website quality. In addition, the results of research conducted by Mohammad and Raeisi (2002) also mentions that reliability has the highest correlation as a criterion of website quality on online bookstore websites in Iran.

With that, it can be concluded that respondents are satisfied with the quality of the Hijup website because overall the website quality on Hijup has an attractive appearance or design and makes it easier for respondents to search and deliver goods carried out by the Hijup website in accordance with respondents' estimates or expectations. These results are reinforced by the theory of Suryani (2013) which concluded that a website that has good quality is one that has a display that facilitates interaction with its consumers so that it can increase attractiveness and shape the satisfaction of these consumers.

Hypothesis 2: From the results of hypothesis testing, it is found that brand image has a positive effect on customer satisfaction. These results support several previous studies conducted by Septiani (2016) which concluded that brand image has a positive influence on customer satisfaction at Bukalapak. Further research conducted by Rahi et al. (2020) also showed that there is a significant positive influence between brand image and customer satisfaction. Research conducted by Maulana and Sunaryo (2018) also said that there is a positive influence between brand image on customer satisfaction at cheap padang restaurants.

The results of the study stated that the better the brand image owned by Hijup, the higher the level of customer satisfaction felt by Hijup consumers. Based on the results of the analysis, the t-statistic is 4.022 and the $p$ value is 0.000 . These results conclude that there is a direct influence of brand image on customer satisfaction.

When viewed based on respondents' answers, the indicator with the highest mean is the symbolic benefits dimension with a mean of 4.346 in the category of strongly agree. This shows that Hijup products can meet the needs of respondents in a social lifestyle so that they can form a sense of satisfaction in the minds of consumers. This supports the research conducted by Santi and Farah (2015) which 
showed the results of symbolic benefits will strengthen brand image which will then affect customer satisfaction. Research conducted by Wang et al. (2009) found that symbolic benefits are the main source of forming customer satisfaction in brand image. Neupane (2015)also showed that the correlation coefficient of symbolic benefits and customer satisfaction as a whole shows positive and very significant results.

The functional benefit dimension with the indicator X2.1 with a mean of 4.335 is included in the category of strongly agree. And the next dimension is experiential benefits with an indicator of X2.5 with a mean of 4.205 which is included in the category of strongly agree. These results indicate that the dimensions of symbolic benefits, functional benefits and experiential benefits have a very important role in the formation of brand image variables that will have a positive influence on customer satisfaction.

Hypothesis 3: From the results of hypothesis testing, Islamic physical attributes have a negative effect on customer satisfaction. Based on the results of the analysis, the t-statistic is 1.576 and the $p$ value is 0.116 , it shows that the relationship between the Islamic physical attributes variable has no significant effect on customer satisfaction.

Based on these results, it shows that Hijup website consumers do not need Islamic physical attributes to create a sense of satisfaction when shopping on the Hijup website. However, if you look at the respondents' answers, the total average of the resulting values has a value of 4.286 or is included in the "Strongly Agree" category. Therefore, respondents in this study who are Hijup website consumers who have made purchases more than once consider that Islamic physical attributes are things that can be considered on a Hijup website, but this is not one of the factors that make consumers feel satisfied when they are on a Hijup website.

Islamic physical attributes variable does not affect customer satisfaction because it can be caused by differences in research objects used in this study. The object in this study is a website-based e-commerce, while in previous studies this variable was used to measure customer satisfaction in the tourism or banking industry in offline form. The difference in the object of research causes different needs that are important for consumers.

The results of this study support the results of previous studies conducted by Rahayu (2018). This study concluded that Islamic physical attributes do not affect customer satisfaction can be caused by differences in the characteristics of respondents. Rahayu (2018) also concluded that Islamic banking customers in Malang have not viewed Islamic physical attributes as very important because banks almost have the same standards.

Some indicators of Islamic physical attributes on the Hijup website that have the lowest mean, such as providing fashion product designs that are in accordance 
with Islamic law, are considered not too important, because at this time various ecommerce fashions in general already provide clothing with Muslim friendly designs. Likewise, the Hijup Website indicator displays a model that covers the genitals, it is considered not too important because the model provided by e-commerce has been adapted to the target market.

The results of this study are not in line with the results of research conducted by Sobari et al. (2019) which said that Islamic outlets atmosphere is believed to be an attribute that attracts Muslim consumers to choose stores which will ultimately form customer satisfaction. Concluded by Farias et al. (2014), which stated that the Islamic atmosphere outlets affect consumer behavior in three aspects. First, according to Soars (2009), Islamic atmosphere outlets function as a means to attract consumers. Second, it is a tool to convey the message that the store expresses the characteristics of its environment (González-Benito et al., 2005). Third, the atmosphere serves as a means of establishing effective conditions, because environmental characteristics such as those mentioned above can trigger internal reactions that contribute positively to the possibility of purchase (Groeppel-Klein, 2005)

Hypothesis 4: Based on the results of research conducted on Hijup website consumers, it shows that customer satisfaction has a significant influence on customer retention. This result can be based on a t-statistic of 11.508 and a $p$ value of 0.000 which proves that customer satisfaction has a positive effect on customer retention because it has met the assessment criteria. This shows that Hijup website consumers agree that customer satisfaction can shape and influence customer retention. Then the highest mean is found in the Hope indicator with the $\mathrm{Y} 1$ category of 4.184 which enters the agree category, this means that Hijup products can meet the expectations of respondents which will form consumer satisfaction.

The results of this study support several previous studies conducted by Chen and Liu (2017) which showed that customer loyalty mediates the relationship between customer satisfaction and customer retention. Bakar and Mudiantono (2010) concluded that customer satisfaction has a positive effect on customer retention in the prepaid cellular card product in the Semarang area. Then the results of this study also support the results of research conducted by Yustine and Fadillah (2015). The results of this study conclude that there is a positive direction between customer satisfaction and customer retention in XL product users in STIE Unity students.

\section{CONCLUSION}

Based on the research that has been done, it can be concluded that website quality and brand image have a positive effect on consumer satisfaction which will mediate consumer retention. Islamic physical attributes variable has a negative relationship with customer satisfaction, and customer satisfaction has a positive relationship with customer retention. 
This research can provide information about consumer behavior in online shopping which can shape satisfaction and ultimately will survive buying at the store even though there are many other choices. However, this study has limitations, the number of respondents used in this study is still quite limited because it was carried out during a pandemic, and the R-Square value in this study is still included in the moderate category or exogenous variable and moderation is not strong enough to explain endogenous variables. In addition, researchers hope that further research can provide knowledge and insight on the topic of customer retention in website-based e-commerce. In this study, the R-Square owned by the customer satisfaction and customer retention variables are still quite small. The researcher suggests further research to add the trust variable to help measure the customer satisfaction variable which in turn will form customer retention in e-commerce.

\section{ACKNOWLEDGMENT}

This research would not have been completed without the involvement of many parties. Therefore, we would like to thank the respondents, and the Hijup website which is the subject and object of our research. In addition, we also thank our colleagues for the various collaborations that have been carried out, to University of Airlangga who has given us the opportunity to conduct one of the marketing research in the field of website-based e-commerce. Especially to the reviewers and the JEBIS editorial team for all the valuable suggestions for our writing. We got a lot of feedback and were given the opportunity to publish on JEBIS. Thank you very much for JEBIS.

\section{REFERENCES}

Ajzen, I., \& Fishbein, M. (1980). Understanding attitudes and predicting social behaviour. Pretince Hall. http://www.citeulike.org/group/38/article/235626

Amirahmadi, M., Raeisi, D., \& Bavar, F. (2015). An Examination of the Effect ofWebsite Quality on Satisfaction and Customer Retention; the Case of Iranian Online BookStores. GMP Review, 16.

Andry, J. F. (2016). THE E-COMMERCE POTENTIAL FOR HOME-BASED BUSINESSES: A CASE STUDY. Jurnal IImiah FIFO, 8(2), 139-146.

Anwar, S., Min, L., \& Dastagir, G. (2019). Effect of Service Quality, Brand Image, Perceived Value on Customer Satisfaction and Loyalty in the Chinese Banking Industry. International Journal of Business Economics and Management Works, 6(3), 24-30. http://www.ijbemw.com/paper/effect-of-service-qualitybrand-image-perceived-value-on-customer-satisfaction-and-loyalty-in-thechinese-banking-industry

Bakar, A., \& Mudiantono, M. (2010). ANALISIS PENGARUH CUSTOMER SATISFACTION, SWITCHING COST, DAN TRUST IN BRAND TERHADAP CUSTOMER RETENTION (Studi Kasus: Produk Kartu Seluler Prabayar simPATI Wilayah Semarang) [University of Diponegoro]. http://eprints.undip.ac.id/24455/ 
Barnes, S. J., Diaz, M., \& Arnaboldi, M. (2021). Understanding panic buying during COVID-19: A text analytics approach. Expert Systems with Applications, 169. https://doi.org/10.1016/j.eswa.2020.114360

Barnes, S., \& Vidgen, R. (2000). WebQual: An Ecploration of Website Quality. ECIS 2000 Proceedings. https://aisel.aisnet.org/ecis2000/74/

Battour, M., Ismail, M. N., \& Battor, M. (2010). The Impact of Destination Attributes on Muslim Tourist's Choice. International Journal of Tourism Research, 13(6), 527-540. https://doi.org/10.1002/jtr.824

Chen, C.-M., \& Liu, H.-M. (2017). The moderating effect of competitive status on the relationship between customer satisfaction and retention. Total Quality Management \& Business Excellence, 30(7-8), 721-744. https://doi.org/10.1080/14783363.2017.1333413

Chikako, T. U., \& Hamu, G. T. (2021). Assessment of Customers' Relationship Management Practices on Customer Retention and Loyalty of Oromia Credit and Saving Share Company: Bule Hora City Branch. Advances in Operations Research, 2021, 5545836. https://doi.org/10.1155/2021/5545836

Daneshfar, Z., Roshani, A., \& Sabzali, H. (2016). Evaluating the Customer Retention and Satisfaction and the Reasons of Losing Customers in the Auto Insurance (A case study). Proceedings of the 2016 International Conference on Industrial Engineering and Operations Management.

Egan, J. (2014). Marketing Communications. SAGE.

Eid, R., \& El-Gohary, H. (2014). Integrating Muslim Customer Perceived Value, Islamic Religiosity and Muslim Customer Satisfaction in Tourism Industry. British Academy of Management.

Farias, S. A. de, Aguiar, E. C., \& Melo, F. Vi. S. (2014). Store Atmospherics and Experiential Marketing: A Conceptual Framework and Research Propositions for An Extraordinary Customer Experience. International Business Research, 7(2), 87-99.

Fariz, M. (2018). Pengaruh Islamic Store Attributes terhadap Patronage Behavior melalui Costumer Satisfaction pada Islamic Based Store. Jurnal Ekonomi, 9(1), 48-57.

Fauzi, W. I. M., Muhammad, N., Mokhtar, S. S. M., \& Yusoff, R. Z. (2016). What Motivate Muslim Consumer to Patronage Islamic Based-retail Store? International Review of Management and Marketing, 6(S7), 199-203. https://dergipark.org.tr/en/download/article-file/367351

Gallo, A. (2014). The Value of Keeping the Right Customers. Harvard Business Review, 29.

Gardiner, S., King, C., \& Grace, D. (2012). Travel Decision Making: An Empirical Examination of Generational Values, Attitudes, and Intentions. Journal of Travel Research, 52(3), 310-324. https://doi.org/10.1177/0047287512467699

Global Religious Futures. (2018). Indonesia, Negara dengan Penduduk Muslim Terbesar Dunia. Databooks. https://databoks.katadata.co.id/datapublish/2019/09/25/indonesia-negaradengan-penduduk-muslim-terbesar-dunia

González-Benito, Ó., Muñoz-Gallego, P. A., \& Kopalle, P. K. (2005). Asymmetric competition in retail store formats: Evaluating inter- and intra-format spatial effects. Journal of Retailing, 81(1), 59-73. 
https://doi.org/10.1016/j.jretai.2005.01.004

Groeppel-Klein, A. (2005). Arousal and consumer in-store behavior. Brain Research

Bulletin, 67(5), 428-437. https://doi.org/10.1016/j.brainresbull.2005.06.012

Hair, J. F., Black, W. C., Babin, B. J., Anderson, R. E., \& Tatham, R. (2006). Multivariate data analysis. Uppersaddle River. NJ: Pearson Prentice Hall.

Hansopaheluwakan, S. (2021). Analysis of e-service quality and website quality effect on e-customer loyalty through e-customer satisfaction (case study:

Tokopedia). IOP Conference Series: Earth and Environmental Science, 794(1), 12086. https://doi.org/10.1088/1755-1315/794/1/012086

Hasanov, J., \& Khalid, H. (2015). The Impact of Website Quality on Online Purchase Intention of Organic Food in Malaysia: A WebQual Model Approach. Procedia Computer Science, 72, 382-389. https://doi.org/10.1016/j.procs.2015.12.153

Hashim, H., Hussin, S. R., \& Zainal, N. N. (2014). Exploring Islamic Retailer Store Attributes from Consumers Perspectives: An Empirical Investigation. International Journal of Economics and Management, 8, 117-136.

Hsieh, S. W., Lu, C. C., \& Lu, Y. H. (2018). A Study on the Relationship Among Brand Image, Service Quality, Customer Satisfaction, and Customer Loyalty - Taking 'the Bao Wei Zhen Catering Team' As an Empirical Study. KnE Social Sciences, 3(10). https://doi.org/10.18502/kss.v3i10.3512

Huang, P.-L. (2019). The influence of service quality on customer satisfaction and loyalty in B2B technology service industry. Total Quality Management \& Business Excellence, 30(13-14), 1449-1465. https://doi.org/10.1080/14783363.2017.1372184

Johnston, R. (2004). Towards a better understanding of service excellence. Managing Service Quality: An International Journal, 14(2/3), 129-133. https://doi.org/10.1108/09604520410528554

Kotler, P., Kartajaya, H., \& Setiawan, I. (2017). Marketing 4.0: Moving from Traditional to Digital. John Wiley \& Sons.

Kotler, P., \& Keller, K. L. (2016). Marketing Management (15th ed.). Pearson education.

Lee, C., \& Lim, S. (2020). Impact of Environmental Concern on Image of Internal GSCM Practices and Consumer Purchasing Behavior. The Journal of Asian Finance, Economics and Business, 7(6), 241-254. https://doi.org/10.13106/jafeb.2020.vol7.no6.241

Malik, M. E., Ghafoor, M. M., \& Iqbal, H. K. (2012). Impact of Brand Image, Service Quality and price on customer satisfaction in Pakistan Telecommunication sector. International Journal of Business and Social Science, 3(23), 123-129.

Mathew, J. (2021). Drivers of Customer Retention: An Introspection Into Indian Retail Customers. Vision: The Journal of Business Perspective. https://doi.org/10.1177/09722629211043592

Maulana, R. R., \& Sunaryo, S. (2018). THE INFLUENCE OF BRAND IMAGE ON CUSTOMER SATISFACTION AND CUSTOMER LOYALTY (A Study at Padang Murah Restaurant in Malang City). Jurnal IImiah Mahasiswa FEB UB.

McDaniel, S. W., \& Burnett, J. J. (1990). Consumer religiosity and retail store evaluative criteria. Journal of the Academy of Marketing Science, 18, 101-112. https://link.springer.com/article/10.1007/BF02726426 
Mohammad, A. F., \& Raeisi, D. (2002). An Examination of The Effect of Website Quality on Satisfaction and Customer Retention.

Napitupulu, D. (2017). Analysis of Factors Affecting the Website Quality Based on Webqual Approach (Study Case: XYZ University). International Journal on Advanced Science Engineering Information Technology, 7(3).

Neupane, R. (2015). The Effects of Brand Image on Customer Satisfaction and Loyalty Intention in Retail Super Market Chain UK. International Journal of Social Sciences and Management, 2(1), 9-26. https://doi.org/10.3126/ijssm.v2i1.11814

Nguyen, H. T., Nguyen, H., Nguyen, N. D., \& Phan, A. C. (2018). Determinants of Customer Satisfaction and Loyalty in Vietnamese Life-Insurance Setting. Economic and Business Aspects of Sustainability, 10(4), 1151. https://doi.org/10.3390/su10041151

Oliver, R. L. (1997). Satisfaction: A behavioral perspective on the consumer. IrwinMcGraw Hill.

Park, H., \& Park, S. (2019). The Effect of Emotional Image on Customer Attitude. The Journal of Asian Finance, Economics and Business, 6(3), 259-268. https://doi.org/10.13106/jafeb.2019.vol6.no3.259

Pradana, M. (2015). Klasifikasi Bisnis E-Commerce di Indonesia. Modus, 27(2), 163174.

Pradana, M., \& Puspitasari, D. N. (2016). Webqual Analysis Of Telkom University's Openlibrary System From The Perspectives Of Communication And Business Students. BAndung Creative Movement (BCM), 3(1). https://openlibrarypublications.telkomuniversity.ac.id/index.php/bcm/article /view/5827

Priansa, J. (2017). Perilaku Konsumen dalam Persaingan Bisnis Kontemporer. Alfabeta.

Rahayu, Y. S. (2018). The Role of Religiosity on The Influence of Muslim Customer Perceived Value To Customer Satisfaction of Islamic Banking. International Journal of Education and Curriculum Application. https://doi.org/10.31764/ijeca.v0i0.2005

Rahi, S., \& Ghani, M. A. (2016). Internet Banking, Customer Perceived Value and Loyalty: The Role of Switching Costs. Journal of Accounting \& Marketing, 5(4), 1-7. https://doi.org/10.4172/2168-9601.1000188

Rahi, S., Ghani, M. A., \& Ngah, A. H. (2020). Factors propelling the adoption of internet banking: the role of e-customer service, website design, brand image and customer satisfaction. International Journal of Business Information Systems, 33(4), 549-569. https://www.inderscienceonline.com/doi/abs/10.1504/IJBIS.2020.105870

Ringle, C. M., Wende, S., \& Becker, J.-M. (2015). SmartPLS 3.

Roy, G., Datta, B., \& Basu, R. (2017). Effect of eWOM Valence on Online Retail Sales. Global Business Review, 18(1), 198-209. https://doi.org/10.1177/0972150916666966

Septiani, A. (2016). Perilaku Konsumen di Era Internet: Implikasinya pada Strategi Pemasaran. UIN Jakarta.

Sheth, J. (2020). Impact of Covid-19 on consumer behavior: Will the old habits return or die? Journal of Business Research, 117, 280-283. https://doi.org/10.1016/j.jbusres.2020.05.059 
Shin, J. I., Chung, K. H., Oh, J. S., \& Lee, C. W. (2013). The effect of site quality on repurchase intention in Internet shopping through mediating variables: The case of university students in South Korea. International Journal of Information Management, 33(3), 453-463. https://doi.org/10.1016/j.ijinfomgt.2013.02.003

Siagian, H., \& Cahyono, E. (2014). Analisis Website Quality, Trust, dan Loyalty Pelanggan Online Shop. Jurnal Manajemen Pemasaran, 8(2). https://doi.org/10.9744/pemasaran.8.2.55-61

Soars, B. (2009). Driving sales through shoppers' sense of sound, sight, smell and touch. International Journal of Retail \& Distribution Management, 37(3), 286298. https://doi.org/10.1108/09590550910941535

Sobari, N., Kurniati, A., \& Usman, H. (2019). The influence of Islamic attributes and religious commitments toward halal wellness services customer satisfaction and loyalty. Journal of Is/amic Marketing. https://doi.org/10.1108/JIMA-112018-0221

Suryani, T. (2013). Perilaku Konsumen di Era Internet: Implikasinya pada Strategi Pemasaran. Graha Ilmu.

Tariq, A., Afzal, A., \& Fiaz, M. (2016). The Impact of Consumer Confidence and Store Attributes on Store Satisfaction and Store Loyalty. Journal of Accounting \& Marketing, 5(4), 1-6. https://doi.org/10.4172/2168-9601.1000200

Usman, H. (2015). Hubungan Religiusitas dan Pemilihan Bank Islam dengan Memperhitungkan Peran Norma Religius, Trust, Importance of Bank Attributes dan Sumber Informasi. Universitas Indonesia.

Wang, W.-H., Liang, C.-J., \& Joonas, K. (2009). Customer Relationship Investments, Value to the Customer, and Value to the Firm: Integrating Attributes and Benefits. Southwest Business and Economics Journal, 23-46.

Wijanto, S. H. (2015). Metode Penelitian Menggunakan Structural Equation Modelling dengan LISREL 9 (1st ed.). Lembaga Penerbit Fakultas Ekonomi Universitas Indonesia.

Yustine, Y., \& Fadillah, A. (2015). Pengaruh Customer Satisfaction dan Trust in A Brand terhadap Customer Retention (Studi Kasus Pengguna Produk XL pada Mahasiswa STIE Kesatuan). STIE Kesatuan. 